УДК 796

DOI $10.21661 / \mathrm{r}-473435$

\title{
Н.А. Воронов
}

\section{ЯРОСЛАВСКИЙ ФУТБОЛ: ВЗГЛЯД В ПРОШЛОЕ И БУДУЩЕЕ}

Аннотация: данная работа рассматривает вопросы зарождения и становления Ярославского футбольного клуба «Шинник». Дается характеристика инфраструктуры самого стадиона. Рассматривается как планировалось провести его реконструкиию изначально к 2010 году в честь тысячелетия и в дальнейтем включение стадиона в список городов в которых будет проводиться Чемпионат Мира по футболу. В статье приводятся статистические данные побед и поражений в различные годы существования клуба.

Ключевые слова: спорт, футбол, игроки, тренер, мяч.

\section{N.A. Voronov}

\section{SOCCER OF YAROSLAVL: FLASHBACK AND FUTURE}

Abstract: this work considers questions of origin and formation of the Yaroslavl football club «Shinnik». The characteristic of infrastructure of the stadium is given, as it was planned to carry out its reconstruction initially by 2010 in honor of the millennium and further inclusion of stadium in the list of the cities in which the FIFA World Cup will be held is studied. Statistical data of victories and defeats in various years of existence of club are provided in work.

Keywords: sport, soccer, players, trainer, ball.

Футбольный клуб Шинник из города Ярославля, безусловно, на слуху у каждого человека, мало-мальски причастного к футболу или просто спорту. Чем он так знаменит? Ведь если взглянуть на текущее положение клуба, то из глаз истинного поклонника клуба может потечь скупая слеза, из уст любого другого футбольного обывателя - звонкий смех. 
Но идет ли речь только про настоящее время? Был ли «Шинник» всегда посредственным футбольным клубом? Может, в Советский период и на стыке XX и XXI веков клуб гремел на всю Россию, и, может, даже Европу? Разберемся.

Давайте же посмотрим, что было с этим футбольным клубом на протяжении истории такого, что заставляет осесть название «Шинник» в большом количестве умов, какие взлеты и падения были у команды и какие личности были к этому причастны [1].

Футбольный клуб Шинник был основан 15 января 1957 года. Интереса ради стоит сказать, что этот день по-настоящему считают днем рождения клуба и ежегодно проводят праздничные события в эту честь. Так, например, на юбилейные для клуба даты - 55 и 60 лет, некоторые трамваи и троллейбусы города Ярославля были окрашены в черно-синие цвета и возили на себе эмблему клуба.

Кстати говоря, черно-синие цвета стали основными для команды только 1 апреля 2001 года, когда игроки впервые появились в них на поле. До этого же у Шинника не было строго определенных цветов на протяжении практически полувека, вплоть до того, что игроки команды играли в красных, желтых, белых и, даже зеленых футболках. Нонсенс. Автором «черно-синей» идеи, как говорил бывший президент клуба Михаил Морозов, стал Александр Михайлович Побегалов - воистину легенда клуба, который и в настоящее время является главным тренером команды. Естественно, не без перерывов.

Гордое название «Шинник», произошедшее от Ярославского шинного завода, клуб также носит не с самого его основания. Первые три года, с 1957 по 1960, игроки имели честь выступать за ФК «Химик» [1].

Что касается эмблемы клуба, то она менялась 3 раза по ходу истории. На первоначальном этапе - с 1961 по 1989 года, эмблема выражала принадлежность к «отцу» клуба - Ярославскому шинному заводу, на которой была изображена шина с футбольным мячом внутри, ярко-красной буквой «Я» и надписью «Шинник». И всё это на коричневом фоне. Настоящее ретро. С 1995 по 1999 года эмблема поменялась в связи со сменой финансирования, и теперь она представляла собой герб Ярославля - медведя (однако, почему-то красного) на фоне 
футбольного мяча. Новая же эмблема, которая привычна и знакома многим, появилась в 2000 году. Она отличается своей простотой - выполнена в форме вымпела в черно-синих цветах клуба, с гербом Ярославля на фоне футбольного мяча. А что еще нужно?

Гостей ярославцы принимают на одноименном с клубом стадионе - «Шинник», вмещающем без малого практически 23 тысячи человек. Грустно, но столько людей он не видел уже большое количество времени, измеряющемся в десятилетиях [2]. Последние аншлаги были зафиксированы на стыке XX и XXI веков. Примечательно, но даже стадион успел войти в историю. Так, в 2002 году на нем установили самое большое электронное табло во всей России. Красиво.

Качество стадиона в настоящее время, конечно, оставляет желать лучшего. Планировалось провести его реконструкцию изначально к 2010 году, в честь тысячелетия [3]. Однако к этому времени была снесена и заново построена лишь одна из четырех трибун - Южная. Затем Россия получила право на проведение Чемпионата Мира по футболу в 2018 году, который, к слову, уже стартует через несколько месяцев. Ярославль включили в расширенный перечень городов, в которых должны были проводиться матчи Чемпионата. Соответственно, была запланирована еще одна реконструкция - уже на средства федерального бюджета. Однако, с грустью приходиться констатировать данный факт, но Ярославль и Краснодар были исключены из окончательного списка городов, и все мечты о новом стадионе в душах ярославских поклонников футбола разрушились.

Ярославль остался в списке городов, но не которые будут принимать матчи самого Чемпионата Мира, а в списке городов-тренировочных баз. В связи с этим стадион свою реконструкцию все-таки получит. Однако, лишь косметическую [4].

Если же обратиться непосредственно к истории футбольного клуба, то ее можно разделить на 2 этапа - Советский и Российский.

На Советском этапе игроки команды провели 1346 матчей, в которых были побеждены 523 соперника, при 447 капитуляциях. Результат не такой плохой. 
Лучшим достижением Шинника стал выход в высшую лигу советского футбола (первая группа класса «А»), в котором, к сожалению, команда заняла лишь 16 место, которое является предпоследним. Это событие произошло в 1964 году. Помимо этого, «Шинник» провел 7 сезонов во второй группе класса «А» (1963, 1965-1970), целый 21 сезон в первой лиге класса «А» - с 1971 по 1991 года. И наконец, 6 лет было проведено в низшем на тот момент, классе «Б» (1957-1962 года). Как видим, в чемпионате СССР команда не сильно выделялась, в основном будучи крепким середняком советского футбола.

Теперь перейдем к более близкому нам, так называемому Российскому этапу. В Чемпионате России «Шинник» провел 668 матчей, в которых были одержаны 269 побед, при 225 поражениях. Опять же, результат не такой плохой. Средний. Лучшим достижением команда может похвастаться в 1997 году, в котором в Высшей лиге было занято 4 место - результат потрясающий. В Высшей лиге (Премьер-лиге) за российскую историю «Шинник» побывал 10 лет (1992, 1997-1999, 2002-2006, 2008). В первом дивизионе - 15 сезонов, 9 из которых-последние 9 лет, начиная с 2009 года (1993- 1996, 2000, 2001, 2007, 2009-2018). Грустно.

Если же обратиться в Кубку России, то лучшим достижением команды стал выход ни много, ни мало - в полуфинал турнира. Это было дважды. В 2004 году было поражение от Грозненского «Терека». Второй же раз произошел... менее месяца назад, 27 февраля 2018 года ярославская команда победила «СКА» из города Хабаровск, и вышла в полуфинал Кубка России, повторив тем самым своё наивысшее достижение четырнадцатилетней давности.

Чем это достижение лучше того, 2004 года? Как минимум тем, что сейчас «Шинник» является командой-середняком второго по значимости дивизиона России, без перспектив повышения в классе, без задач, без финансовых возможностей. И всё это на протяжении последних 9 лет [4]. Сильное достижение при таком букете. И это не предел. В полуфинале ярославцам достался не самый сильный соперник, который ничем не лучше, а, может, даже и хуже Шинника в настоящий момент - Курский «Авангард», который печётся с нами в одном 
котле - в Футбольной Национальной Лиге - второй по значимости в России, причем на более низком месте. Кто знает, может, время обновить историю клуба? Два шага - победа в полуфинале и в финале, и история ФК «Шинник» будет переписана новыми чернилами.

Так что же такое феномен Шинника? Почему об этом клубе знают не все, но многие поклонники футбола и просто спорта? Как мы видим, в настоящее время, да и последние лет 15, «Шинник» может вызывать только лишь усмешки. В советский и ранний российский период также особых успехов не было. Были лишь всплески.

\section{Список литературы}

1. Андреев С.Н. Играй в футбол / С.Н. Андреев/ - М.: Паматур, 1999. - 450 с.

2. Волков Л.В. «Теория и методика детского и юношеского спорта / Л.В. Волков - Киев: Олимпийская литература, 2003. - 280 с.

3. Воронин С.М. Особенности личностно-ориентированной физической подготовки / С.М. Воронин, Н.А. Воронов, Л.Ю. Шалайкин, Е.В. Игнатова // Вестник Костромского государственного университета им. Н.А. Некрасова. - 2015. - Т. 21. - №2. - С. 233-235.

4. Мировой спорт за 100 лет. Факты, события, рекорды. - М.: Рипол Классик, 2017. - 31 с.

\section{References}

1. Andreev, S.N. (1999). Igrai v futbol., 450. M.: Pamatur.

2. Volkov, L.V. (2003). "Teoriia i metodika detskogo i iunosheskogo sporta., 280. Kiev: Olimpiiskaia literatura.

3. Voronin, S.M., Voronov, N.A., Shalaikin, L.Iu., \& Ignatova, E.V. (2015). Osobennosti lichnostno-orientirovannoi fizicheskoi podgotovki. Vestnik Kostromskogo gosudarstvennogo universiteta im. N.A. Nekrasova, 2, 233-235.

4. (2017). Mirovoi sport za 100 let. Fakty, sobytiia, rekordy. M.: Ripol Klassik.

Воронов Николай Андреевич - канд. биол. наук, старший преподаватель ФГКВОУ ВО «Ярославское высшее военное училище противовоздушной 
обороны» Минобороны России; доцент ФГБОУ ВО «Ярославский государственный университет им. П.Г. Демидова», Россия, Ярославль.

Voronov Nikolay Andreevich - candidate of biological sciences, senior lecturer at the Yaroslavl Aerospace Military Academy of the Ministry of Defence of the Russain Federation; associate professor at the Yaroslavl state university named after P.G. Demidov, Russia, Yaroslavl. 